\title{
PROPOSITION OF A SIMPLIFIED PROTOCOL AND NEW PARAMETER INTRODUCTION IN NMRI MICE ANHEDONIA INDUCTION
}

\author{
Elsa Fedrigolli ${ }^{1}$, Damir Bogdan ${ }^{2}$, Dušan Lalošević ${ }^{3,4}$ and Pavle Banović1,3 \\ ${ }^{1}$ University of Novi Sad, Medical faculty Novi Sad, Novi Sad, Serbia \\ ${ }^{2}$ University of Novi Sad, Faculty of Philosophy, Department of Psychology, Novi Sad, Serbia \\ ${ }^{3}$ Pasteur Institute Novi Sad, Novi Sad, Serbia \\ ${ }^{4}$ University of Novi Sad, Medical faculty Novi Sad, Serbia
}

\section{PREDLOG ZA POJEDNOSTAVLJEN PROTOKOL I UVOĐENJE NOVOG PARAMETRA KOD IZAZIVANJA ANHEDONIJE KOD NMIRI MISEVA \\ Elsa Fedrigolli ${ }^{1}$, Damir Bogdan ${ }^{2}$, Dušan Lalošević ${ }^{3,4}$,Pavle Banović* 1,3 \\ ${ }^{1}$ Univerzitet u Novom Sadu, Medicinski fakultet, Novi Sad, Srbija \\ ${ }^{2}$ Univerzitet u Novom Sadu, Filozofski fakultet, Departman za psihologiju, Novi Sad, Srbija \\ ${ }^{3}$ Pasterov zavod Novi Sad, Novi Sad, Republika Srbija \\ ${ }^{4}$ Univerzitet u Novom Sadu, Medicinski fakultet, Katedra za histologiju i embriologiju, Novi Sad, Srbija}

\begin{abstract}
Introduction: A broad spectrum of research involving stress and stress protocols has long proven that a point of anhedonia, social defeat and learned helplessness can be achieved and observed - with anhedonia being a clinical symptom of Anxiety, Depression and Bipolar Affective Disorder. Aim: The aim of this study is the development of a simplified protocol for anhedonia induction in NMRI male mice in order to shorten the period of mice suffering and decrease complexity of the procedure for other researchers and introduction of new parameter in order to achieve better standardization of results. Materials and Methods: 21 male NMRI mice were introduced to 2 different stress protocols (one found in literature and one simplified) where cognitive-behavioral status was tested using the Sucrose Preference Test, Open Field Test, Grooming Pattern and histological examination of adrenal glands, and to propose a new protocol for fellow researchers. Results: Results observed include the successful induction of anhedonia proven by Sucrose Preference Tests, Barbering effect and microhemorrhage of the adrenal glands. Simplified protocol showed superiority compared to the one found in literature. Conclusion: Simplified protocol showed higher efficiency and reduced amount of work during testing phase. Introduction of NMI as a new parameter during behavioral evaluation resulted in better standardization of measured SPT values that incorporates common knowledge of mammal physiology. A big developmental step was the introduction of the Normalised Mass Index to even out mass fluctuations and differences in basal metabolism, which we recommend to other researchers and institutions.
\end{abstract}

Keywords: Chronic stress protocol; anhedonia; anxiety; depression; NMRI mice

\section{SAŽETAK}

Uvod: Spektar istraživanja koja uključuju stres i protokole vezane za njega su dokazala da stanje anhedonije može biti postignuto i posmatrano kao stanje analogno depresiji, anksioznim i bipolarnim poremećajima kod ljudi. Cilj:Cilj ove studije je da se korišćenjem alternirajućih stresora dovede do skraćivanja perioda potrebnog za dostizanje stanja anhedonije kod mužijaka miša soja NMRI. Materijali i metode:Korišćenjem parametara dobijenih testom preferencije šećera (SPT), testom otvorenog polja, posmatranjem obrazaca održavanja krzna, merenjem telesne mase i histološkom analizom nadbubrežnih žlezda izvršena je komparacija efektivnosti novog protokola naspram procedure prisutne u literaturi. Usled fluktuacije telesne mase jedinki tokom eksperimenta uveden je novi parametar (Normalizovani maseni indeks - NMI) radi standardizacije rezultata dobijenih SPT analizom. Rezultati: Nalazom SPT parametara, efekta samobrijanja i mikrohemoragije u nadbubrežnim žlezdama predloženi protokol je nakon 28 dana eksperimenta pokazao superiornost naspram kontrolnog protokola .Uvođenje NMI se pokazalo kao značajan korak u procesu normalizacije rezultata. Podjednostavljen protokol je pokazao ukupnu superiornost naspram kontrolnog protokola. Zaključak: Podjednostavljen protokol izazivanja anhedonije je pokazao veću efikasnost $i$ doveo do smanjivanja utroška radnog vremena istraživača skraćivanem perioda potrebnog za dostizanje stanja anhedonije kod mužijaka miša soja NMRI. Uvođenje NMI kao novog parametra rezultovalo je boljom standardizacijom merenih SPT vrednosti.

Ključne reči: stres, anhedonija, depresija, anksioznost, miš, NMRI 


\section{INTRODUCTION}

In the boom of mood disorders such as depression, anxiety and bipolar affective disorder it comes to no surprise that stress besides genetic and environmental variables is held accountable as a major source triggering those illnesses (1-4). With this being said stress can be subdivided into psychological, physical, physiological and environmental stress $(1,5-$ 6). Each of them is a plausible stressor in humans and can lead to mood changes, anhedonia, energetic changes, difficulty in concentration and memory, disrupted circadian circuits, decreased or increased sensation of hunger and finally suicidal thoughts (7). A common belief for above mentioned symptoms is now that humans far derived way of living, such as light exposure during night, are major contributing features that deepen not only the anhedonic state, but also anxiety-relating behavior and further explains why mood disorders are continuously on the rise $(2,8-10)$.

Some of the most important indicators for stress are Cortisol and Corticosterone in the human and Corticosterone in the rodent. Both of these steroid hormones follow a circadian rhythm by peaking in the morning and lowering down slowly throughout the day, reaching its minimum during the night and are used as markers as both of them regulate Gluconeogenesis and suppression of immunity during stressful events amongst many other important functions (5). Glucocorticoids, which are produced in the adrenal cortex, are part of the hypothalamic-pituitary-adrenal axis (HPA axis) system. This system includes the hypothalamus, which via secretion of corticotropin releasing factor (CRF) stimulates secretion of adrenocorticotropic hormone (ACTH) in the anterior pituitary gland $(6,11)$.

Heim et al. (12) suggests that a chronic exposure to stress, especially during childhood, determines vulnerability and leads to a hypersecretion of CRF from the hypothalamus and therefore causes a down-regulation of CRF receptors in the adenohypophysis, which induces anxiety and depression-like symptoms. Based on previous findings it is known that receptors of the HPA-axis can undergo epigenetic modifications during stressful periods and the three-hit concept further explains that based on genetic variables, experiences in early and later life coping with stress leads to vulnerability or resilience and finally as far as to the development of a mental disorder (13-15). This concept comprises the cumulative stress hypothesis (stress and misfortune adding up and leading to disease) and the mismatch hypothesis (mismatch between early and later life leading to the development of a mental disorder) (14).

It is important to mention that the HPA axis influences the HPG axis (the hypothalamic-pituitary-gonadal axis), especially during stress. Higher glucocorticoids hereby mean a suppression of gonadotropin releasing hormone (GnRH), gonadotropins and gonadal function (16-17). The impact of chronic stress on the testes depends if it was applied pre-puberty or during adulthood. Pre-puberty stressed mice show hereby reduced tubular compartment with the danger of reduced fertility. Meanwhile, changes in adult mice are reversible. Most common pathohistology seen in testes after stress exposure is vacuoles in the seminiferous epithelium and degeneration of primary spermatocytes (17).

Although the communication problem between animals and humans does not provide us with insight into the animals mind, animal models have become a valid model for mood disorders as anhedonic state, learned helplessness, social defeat and grooming behavior can be observed and/or measured $(3,18)$. The animals state of coat can in a figurative sense be applied to human appearance and is therefore commonly used for interpretation of the degree of anxiety, depression, obsessive-compulsive disorder, etc $(3,19)$. Sucrose Preference Test, Open Field Test, Forced Swimming Test and more have been widely recognized and acknowledged in mood disorder studies (3). There are several protocols used for anhedonia induction in NMRI mice in order to study mechanisms of depression, anxiety, medications, etc. Most of them require complex alternation of stressors during several weeks in order to reach detectable state of anhedonia.

The aim of this study is the development of a simplified protocol for anhedonia induction in NMRI Mice in order to shorten the period of mice suffering and decrease complexity of the procedure for other researchers and introduction of new parameter in order to achieve better standardization of results.

\section{METHODS AND MATERIALS}

\section{Animals}

Experimental animals were treated in coordinance with Ethical norms of Pasteur Institute Novi Sad (permission number $01-35 / 3)$. A total of 21 male NMRI mice were used for the development and evaluation of a simplified protocol for anhedonia induction. Hereby three cages $(27 \times 20,5 \times 14 \mathrm{~cm})$ with 7 mice each were utilized. Age of mice at the beginning of the experiment was 4 weeks for positive control group (CRTL+), experimental (EXP) and between 7 and 8 weeks for negative control group CRTL-. The control group was reused as part of the Replacement, Refinement and Reduction Guideline for animal research. Room temperature was kept constant at $23 \pm 2{ }^{\circ} \mathrm{C}$. Mice were habitated according to a 12 hour dark-light circadian rhythm and each group was kept in separate room. Mice were kept on a rodent pellet diet and acified water was provided ad libitum except during Sucrose Preference Test. The bedding was changed accordingly to need which varied depending on the stress protocol but minimally once a week. Aggressiveness between mice and rats was tested in a week-long pilot before starting the study, as one stressor specifically required for exposure to one male Wistar rat. After group division by randomization mice were given 7 days before starting the experiment to acclimatize within their group. 


\section{Stress Procedure}

CRTL- group was non-stressed and used for reference values in SPT tests, weight measurements and grooming patterns, whereas both experimental groups underwent several stressors. The experiment lasted for 28 days, after which EXP and CRTL + mice were humanely euthanized (Figure 1).

CRTL + group followed a well-developed Chronic Stress Protocol found in literature [3] that included Rat Exposure, Restraint (Immobilization), Water Emergency, Forced Swimming Test and Tail Suspension (Figure 1).

Meanwhile EXP group underwent a newly designed protocol which consisted of a combination of Immobilization, Dim Lighting, Rat Exposure, Forced Swimming Test, Sound, Tail Suspension and Bedding with Cat Odor (Figure 1).

After the 28 day EXP group reached anhedonic state and stress protocol was over. Mice were kept one more week before being humanely euthanized by neck dislocation. Their adrenal glands were taken and examined using histological routine techniques in order to register potential morphological changes.

\section{Immobilization}

Immobilization Chambers $(10,5 \times 3 \mathrm{~cm}$, polyethylene with cork screw) were always washed with hot water after usage as to remove shed hair and the smell of urine and feces.

\section{Forced Swimming Test (FST)}

Forced Swimming Test was done in a polyethylene cylindrical container using water at room temperature at a height of around $12,5 \mathrm{~cm}$.

\section{Bedding with Cat Odor}

Fifty grams of bedding with cat odor was placed on top of conventional rodent bedding and when it was dismissed another fifty grams was added.

\section{Sound}

When sound was used as a stressor white radio noise or normal radio sounds were turned on in a separate laboratory, which mice were previously transported to.

\section{Dim Lighting}

As with the previous stressor Dim lighting was carried out in our laboratory by applying light from a dim light source over night.

\section{Tail Suspension}

When undergoing Tail Suspension mice were taped to a pole by using laboratory labeling tape. Tail climbing could not always be completely avoided.

\section{Testing}

Sucrose Preference Test, Open Field Test, Body weight and Grooming were used to measure stress effect, anhedonia and anxiety in mice following literature protocols [3]. Adreanal glands were histologically analyzed.

\section{Sucrose Preference Test (SPT)}

Twelve hours prior to testing of Sucrose Preference, mice were derived of food and water. Then both water and a mixture of $1 \%$ sucrose solution was provided and left for 24 hours. Water and Sucrose Solution Intake was measured and Sucrose Preference was concluded by using the formula:

$$
S P T=\frac{\text { Sucrose solution }(g)}{\text { Sucrose solution }(g)+\text { water }(g)} \times 100
$$

If sucrose preference was higher than $65 \%$ mice were termed resilient, if it was lower than $65 \%$ they were termed susceptible.

Furthermore a "Normalised Mass Index" (NMI) was calculated using the following formula:

$$
\begin{aligned}
N M I=\frac{\text { Sucrose solution }(g)}{\text { Sucrose solution }(g)+\text { water }(g)} \\
\quad \div \text { mean weight of mice }(g) \times 100
\end{aligned}
$$

NMI was introduced within this research to reduce error considering that mean weight fluctuated for both experimental groups and therefore had impact on their Basal Metabolism requirements. The NMI was not previously found in literature.

\section{Open Field Test}

Open Field Test (OFT) was examined over a time frame of four minutes by recording the arena via camera (Canon EOS D700) and analysed using computer software ToxTrac v2.83 to examine mobility, average speed and number of bolus dropped per mice. [20] OFT was conducted in arena with base dimensions $40 \mathrm{~cm} \times 40 \mathrm{~cm}$ of opal white color and transparent acrylic walls high $35 \mathrm{~cm}$. Arena was cleaned with $70 \%$ ethanol after recording of each mouse.

\section{Body weight measuring}

Mice body weight was measured the day before each Sucrose Preference Test in the morning period and calculated as average body weight per group. Body weight changes over the course of time were compared between groups using Wilks' Lambda Multivariance Analysis.

\section{Grooming Behaviour}

Grooming behavior was checked three times throughout the experiment by putting a see-through, clear acrylic glass cover over the cage and videotaping the mice in their habitat. The grooming itself was judged by the strokes, patterning of bouts, duration and overall state of coat. 


\section{Histological examinations of adrenal glands}

Adrenal glands were fixated in buffered $10 \%$ formalin ( $\mathrm{pH} 7.4$ ), dehydrated using routine ethanol-xylene sequence and embedded in paraffin (Histowax, Gotenburg) at $60^{\circ} \mathrm{C}$. Histological slides were cut on Leica RT350 rotary microtome, stained by Eriochrome-cyanine R \& Eosin technique according to Stefanovic et al. [21] and photographed by camera mounted on Leica DM microscope.

\section{Statistical analysis}

Data was analyzed using the SPSS software (IBM, USA). Pearson Correlation was used for comparison and evaluation of Normalised Mass Index regarding SPT values. Wilks' Lambda Multivariante test was used for comparison of average body weights between groups during experiment. Twotailed Student t-test was used for comparison of parameters aquired through Open Field Test. Statistically significant difference was considered at $\mathrm{p} \leq 0.05$.

\section{Complications}

Both rat exposure (group CRTL+) and bedding with cat (group EXP) odor seemed to be minor stressors for mice. After initial shock, consensual grooming was seen in the interaction of rat and mice. The rat was later replaced. Cat bedding was completely dismissed by EXP mice, as they hid the cat sand under their normal bedding.

One mouse was eaten by its comates in Protocol EXP during the second Sucrose Preference Test. It was later concluded that this was due to the fact that the mouse itself had scratched open its nose during immobilization (air holes) and this way created a wound. The mouse was removed and tests were normally continued.

\section{RESULTS}

\section{Stress effect on body weight}

Using Wilks' Lambda Multivariance Analysis and Bonferroni post hoc test have found statistically significant difference in average body weight in the course of experiment between CTRL - on the one side and CTRL + and EXP on the other, which is caused by implementation of $3 \mathrm{R}$ principle (Figure 1).

\section{Anhedonia induction}

Regarding SPT values, experimental group was only one that reached near-anhedonic state during 28-day-course of experiment(Figure 3). Despite measured values, a need for adequate standardization was noticed due to average body mass difference, therefore Normalised Mass Index was introduced (Figure 4), which showed correlation with measured SPT values; 0.969;0.896 (Table 1) . Although, positive control group was very near the cutoff point of $65 \%$ on 21 st day of experiment, a week later their results showed higher values in contrast to experimental group. Negative control group showed constant SPT values during the whole course of the experiment.

Table 1. Correlation of NMI and SPT values

\begin{tabular}{lcccc} 
& $\begin{array}{c}\text { NMI } \\
\text { exp }\end{array}$ & $\begin{array}{c}\text { SPT_e } \\
\mathbf{x p}\end{array}$ & $\begin{array}{c}\text { NMI_cr } \\
\text { tl + }\end{array}$ & $\begin{array}{c}\text { SPT_ctrl } \\
+\end{array}$ \\
\hline NMI_exp & 1 & $0.969^{*}$ & 0.773 & 0.411 \\
\hline SPT_exp & $\begin{array}{c}0.969 \\
{ }_{*}\end{array}$ & 1 & 0.805 & 0.471 \\
\hline NMI_ctrl + & 0.773 & 0.805 & 1 & 0.896 \\
\hline SPT_ctrl + & 0.411 & 0.471 & 0.896 & 1
\end{tabular}

\section{Open Field Test (OFT)}

Results obtained from OFT include average speed, average mobility and total fecal boli dropped by individual animal in one group. Student's t-test showed no statistical difference between groups in average speed and mobility. In contrast, there is a significant difference between CTRL + and EXP group in dropped fecal boli per animal $(p=.34)$, where average number of fecal bolus in CTRL+ group is 4.3 and 1.0 in EXP group. 
Figure 1. Depiction of Stress Protocols CRTL-,

CRTL+ and EXP and time line when Sucrose Preference Test (SPT),

Open Field Test (OFT), Grooming (G) and Weight Measurement (W) was carried out.

NEGATIVE CONTROL GROUP
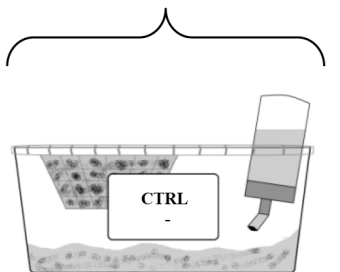

POSITIVE CONTROL GROUP

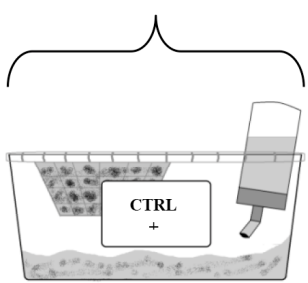

G
W,SPT,OFT G
EXPERIMENTAL GROUP

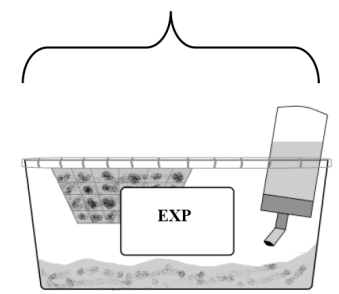

W,SPT G W,SPT

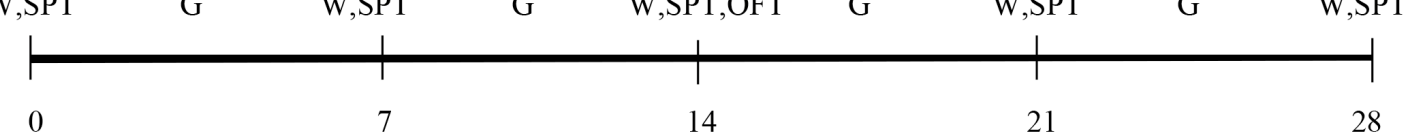

Protocol CRTL-

28 days (d)

口NO STRESSORS

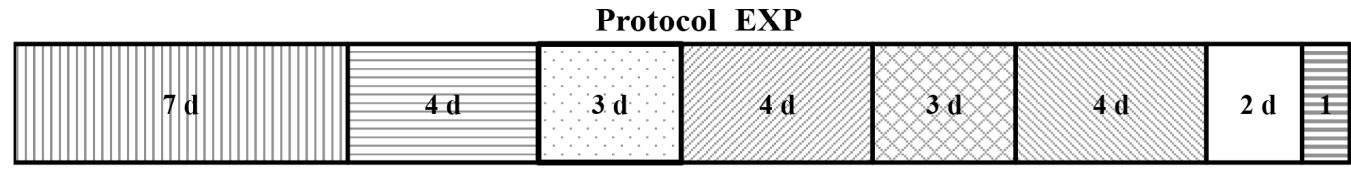

$\square$ IMMOBILIZATION $(2 \mathrm{~h})+$ DIM LIGHTING

IMMOBILIZATION (4h) + RAT EXPOSURE (24h)

口FORCED SWIMMING TEST (6min)

口FORCED SWIMMING TEST (6min) +SOUND (1h)

口IMMOBILIZATION (2h)+TAIL SUSPENSION (6min)

घBEDDING WITH CAT ODOR (24h)+FST (6min)

口IMMOBILIZATION (2h)+FST (6min)

曰IMMOBILIZATION (2h)+ TAIL SUSPENSION (6min)

Protocol CRTL+

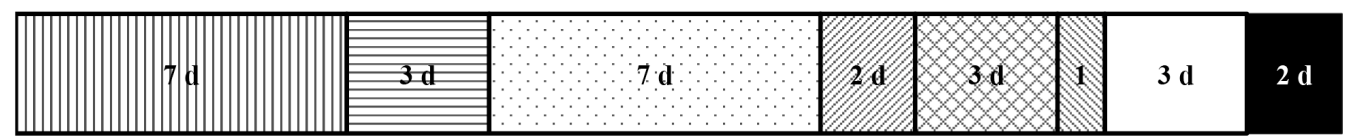

凹 RAT EXPOSURE (24h)

曰RESTRAINT $(2 h)$

口RAT EXPOSURE IN SMALL CONTAINERS (3-12h)

口WATER EMERGENCY

口 RESTRAINT $(2 h)+$ WATER EMERGENCY

口TAIL SUSPENSION (20min)

口TAIL SUSPENSION (6min) + WATER EMERGENCY

- TAIL SUSPENSION (6min) + RESTRAINT (2h) 
Figure 2. Average body weight over the course of the experiment.

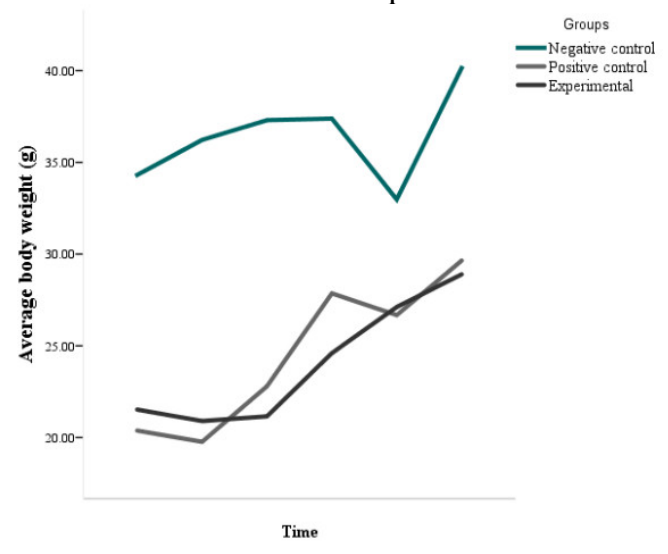

Statistically significant difference in CTRL - group is present due to implementation of $3 \mathrm{R}$ principle

Figure 3. SPT values.

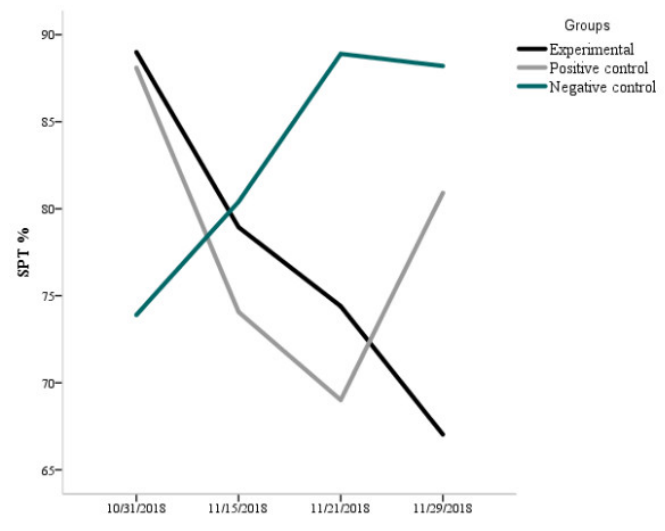

EXP group was the only one that reached near-anhedonic state

Figure 4. NMI values.

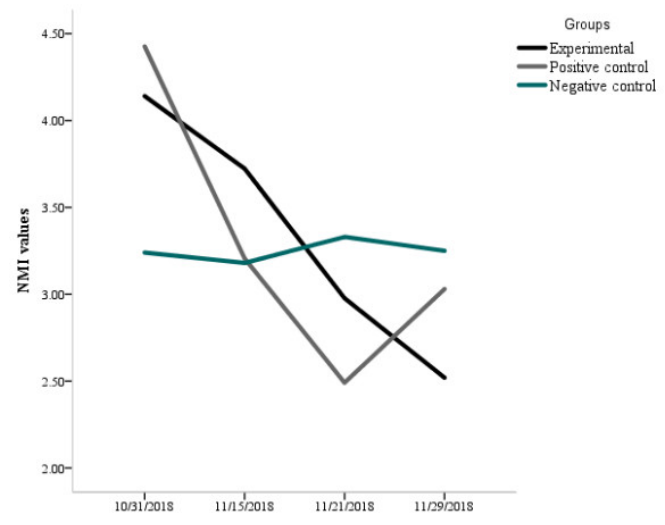

EXP group is still having the lowest score. In contrast to SPT values, CTRL - group is showing a more constant trend through NMI

\section{Grooming Behaviour}

After first week of experiment, one of the most prominent features in the EXP group was the occurrence of the Barbering effect with an exposure of the ventral abdominal surfaces in two mice and indication of exposure of the neck in another one. (Figure 5) It is worth mentioning at this point that their whiskers (crucial sensory organ) and the snout was intact. This Barbering effect disappeared in week four, when 'milder' stressors such as cat bedding were used. Nevertheless, state of coat deteriorated tremendously.

For CRTL+ the coat worsened immensely in the last two weeks of the experiment by thinning out. Stress (FST, Immobilization, etc) led to hyperactivity and excessive grooming with missing strokes and/or decreased or increased duration. Rat exposure was an exception as heterogrooming was seen until the rat was exchanged. The question if anhedonic, stress-evoked mices grooming prolonged or shortened was not uniform in neither of the groups. In a non-stress-evoked, resting state mistakes were seen either as a prematurely terminated bout or as a bout with skipped transitions. A prematurely terminated bout often led to the immediate restart of a new cephalocaudal bout or continuation of the already started one after a few seconds.

Figure 5. Barbering effect seen in EXP group

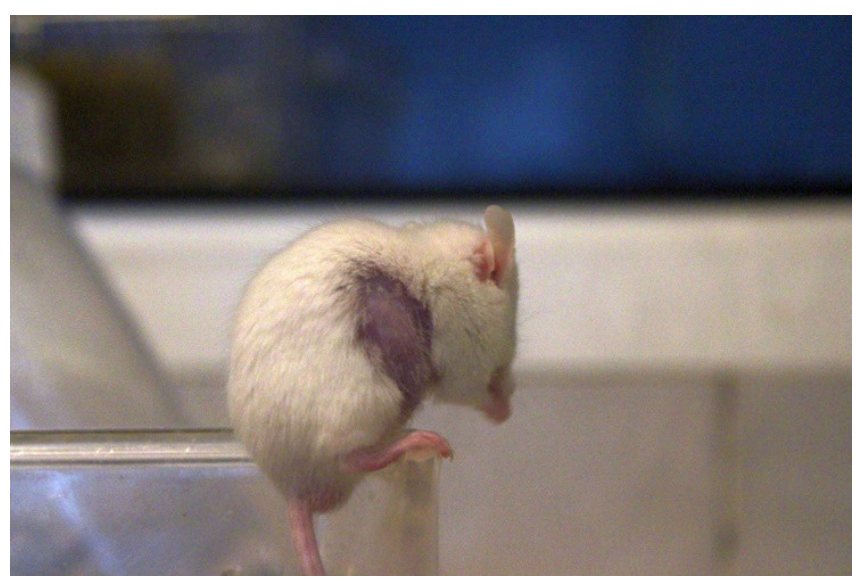

\section{Histological Findings}

Histological examination of adrenal glands revealed dilatation of blood vessels in CTRL+ (Fig.6a-b) and EXP group (Fig. 6e-f) compared to CTRL- group (Fig 6c-d). There is a noticeable hyperemic zone between the medulla and cortex in both stress-induced groups that can be analog to nontraumatic adrenal hemorrhage in humans. 


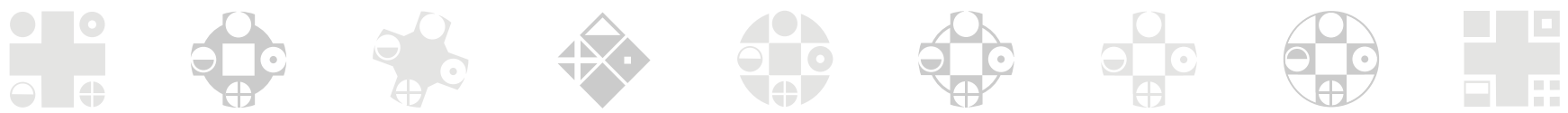

Figure 6. Adrenal glands (ECR\&E; x200;x400)

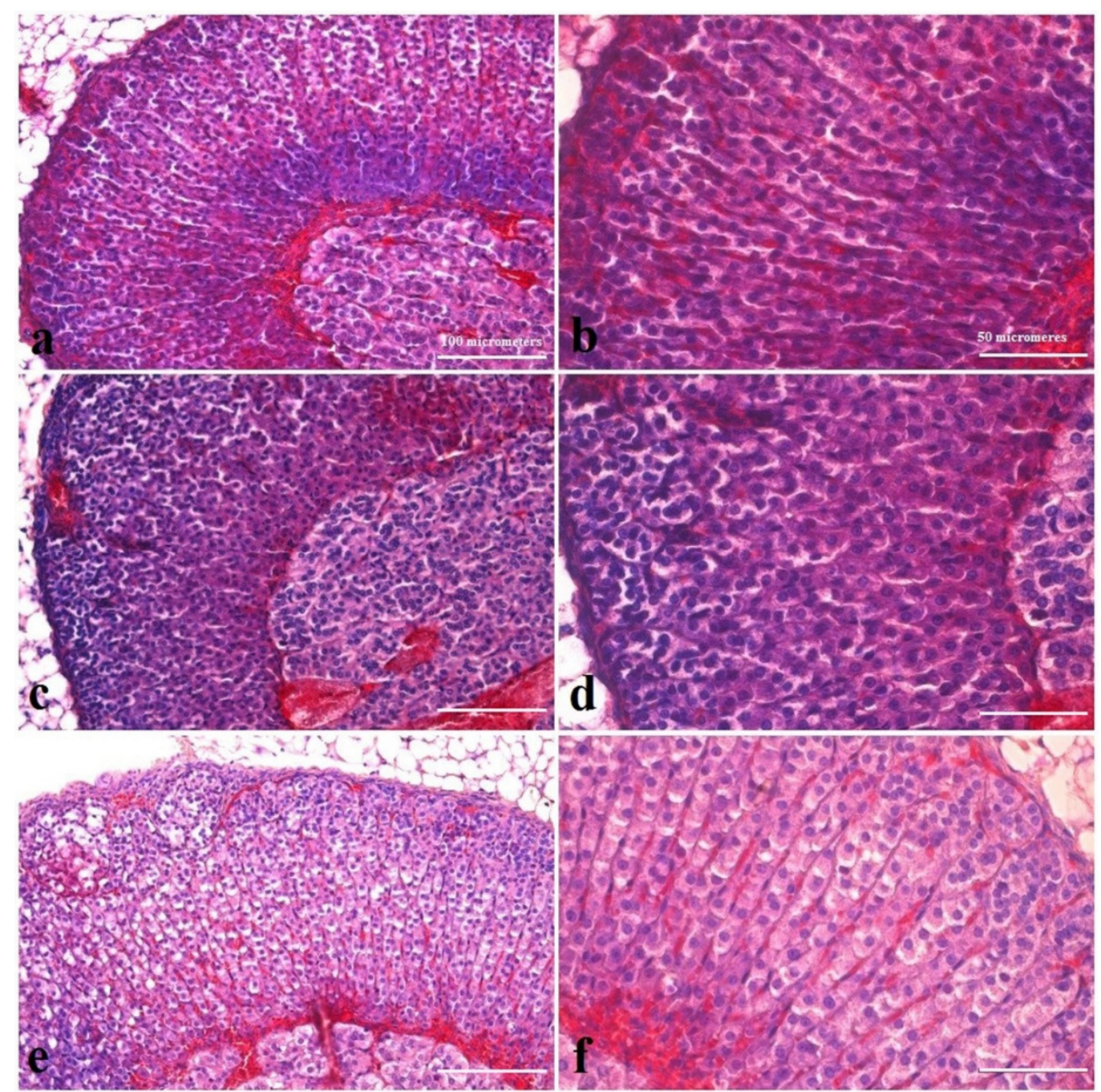

a-b: Hyperemia with microhemorragia in the zone between medulla and cortex and dilatation of cortical blood vessels in the four mice of CTRL+ group . c-d: Normal histological finding in CTRL - group, absence of hyperemia, microhemorragia and dilated blood vessels . e-f: Four mice of the EXP group shows similar findings as CTRL+ group.

\section{DISCUSSION}

The aim of this study was to create a simplified protocol for anhedonia induction in order to minimize suffering of mice and reduce the amount of work needed to achieve the anhedonic effect. Regarding the SPT findings, highlights observed were hereby the occurrence of the Barbering effect as a sign of anxiety and adrenal microhemorrhage due to disruption of the HPA axis.

One of the most outstanding occurrences was the Barbering effect observed in EXP group. NMRI mice are known to show high levels of grooming with frequent manifestations of the Barbering effect (approximately $80-100 \%$ of the time). This has been commonly interpreted as a way of mice to show social dominance, especially in same-sex cages and more commonly in males, and affecting their snouts and whiskers (the Dalila effect). The coping hypothesis furthermore states that inadequate housing leads to this effect (2224). However, close observation and recording of EXP group lead to the clear result that the Barbering effect in this experiment was not due to hetero-grooming, but due to self-grooming, that neither snout not whiskers were affected and that the inadequate housing was not to blame for this occurrence, as CRTL + was exposed to the exact same living conditions, but was completely unaffected. The only difference between the experimental groups was in fact the stress protocol that they underwent. Interpretation of this stress-evoked Barbering from a behavioral standpoint can be attributed to subdivisions of Obsessive Compulsive Disorder (OCD) such as Trichotillomania which constitutes as compulsive hair pulling due to increased self grooming or Anxiety Disorders. These are both related to elevated anxiety levels and can be seen in humans as nail biting, hair pulling and skin picking. Interestingly 
enough, the appearance of the symptom of anhedonia contributed to Major Depression Disorder (MDD) has been said to lead to decreased self-grooming and as a consequence to bad hygiene (19). A possible explanation therefore could be strain specific differences - NMRI mice naturally show higher grooming levels and are naturally more prone to Barbering. Further research needs to be done for better understanding of Barbering effect in relation to strain specific characteristics and behavioral impact.

A downfall during this study was the cannibalism observed during the second Sucrose Preference Test in experimental group EXP. This unfortunately occurred after immobilization as the mouse had a wound on its nose and neither food nor water were supplied overnight. The next morning, when water and sucrose solution were added, the mouse was found dead with parts of its head eaten. The question hereby is if the 12-hour period with food and water derivation is too long to bear for animals? It has to be mentioned that besides this incident no mouse was harmed during Sucrose Preference Testings and although this period itself can be classified as a stressor, it proved to be both bearable for mice and practical for veterinary assistance. This could of course be shortened to a 6-hour derivation phase with a following 8 hour Sucrose Preference Test, which could be question to further research.

Another fail was bedding with cat odor as a stressor as mice dismissed it completely. This came to a surprise since there is scientific research on trace amine-associated receptors (TAAR) in mice noses, especially trained for smells of predators, as is cats urine (25). The most probable answer to this is that there was not enough cat bedding in the cage or that the smell wasn't strong enough. The boundaries should be tested, as filling the entire cage with bedding with cat odor could overpower mice receptors. A possible solution could be supplying a tissue that has been used to pet a cat and putting it into the cage. As no reaction was seen during this experimentation, we have to further ask ourselves if this can provide a form of psychological stress as in social defeat.

Results of the Open Field Test were unclear. It has been proven that there is a negative relationship between ambulation and defecation, meaning that anxious mice will show reduced locomotion with increased stimulation of the autonomic nervous system, which in turn increases defecation. The latter has been often been linked to emotionality or the presence of an affective state $(3,26-27)$. In this experiment, however, speed and mobility didn't show statistically significant difference, yet boli drop did. Hereby CRTL+ group showed increased boli drop and EXP group decreased boli drop with both of them showing a deviation from the norm even though into two opposite realms. Although there are no data for comparison regarding NMRI mice, same results were obtained in the study by Fedotova et al. in prenatally stressed male Wistar rats (28).

A rare revelation that was seen in positive control and experimental group are microhemorrhagic zones between the medulla and cortex. This occurrence can be linked to nontraumatic adrenal hemorrhage in humans, which is a rare stress-induced condition. The stress that leads to the manifestation of nontraumatic adrenal hemorrhage in humans is said to be due to surgery, sepsis, burns, hypotension or pregnancy (29-30). Mice in this experiment underwent several different stressors of different families (physical, physiological, environmental, psychological), with most of them leading to shock and/or crisis in mice. There are several factors deemed responsible for this incident. Firstly, mice used were very young. Adrenal hemorrhage is more likely to occur in neonates than in adults and although mice weren't neonates, they were still more susceptible to adrenal damage than adults. Second, some stressors might have led to hypoxia (f.e. immobilization). Third and most importantly, it seems undeniable that a disruption of the HPA axis is to some degree responsible for adrenal hemorrhage $(6,11,29-30)$.

Further research should focus on strain difference, as well as germ and germ-free animals, and its entanglement when it comes to Grooming pattern, Open Field Test and Sucrose Preference Test. Furthermore, more emphasis should be put onto the study of different mouse strains and stressors and their entanglement.

\section{CONCLUSION}

Compared to anhedonia-inducing stress protocol found in literature, the simplified protocol showed higher efficiency and reduced amount of work during testing phase. Introduction of NMI as a new parameter during behavioral evaluation resulted in better standardization of measured SPT values that incorporates common knowledge of mammal physiology. Regarding our difficulties with the comparison of OFT results with other studies there is a need for improvement and standardization of tests used for behavioral status of mice.

\section{CONFLICT OF INTERESTS}

None.

\section{REFERENCES}

1. Depression - Genetics Home Reference - NIH. U.S. National Library of Medicine. National Institutes of Health; Available from: https://ghr.nlm.nih.gov/condition/depression\#genes

2. Depression. World Health Organization. 2018. Available from: https://www.who.int/news-room/fact-sheets/ detail/depression

3. Gould TD, Dao DT, Kovacsics CE, Smolinsky AN, Bergner CL. (2009). Mood and anxiety related phenotypes in mice: characterization using behavioral tests. Vol. 42. New York: Humana Press; p. 1-119, 261-277.

4. Venzala E, García-García A, Elizalde N, Tordera R. Social vs. environmental stress models of depression from a behavioural and neurochemical approach. European Neuropsychopharmacology 2013; 23(7): 697-708. 
5. Hannibal EK, Bishop MD. Chronic Stress, Cortisol Dysfunction, and Pain: A Psychoneuroendocrine Rationale for Stress Management In Pain Rehabilitation. Phys Ther 2014; 94(12): 1816-1825.

6. National Research Council (US) Committee on Recognition and Alleviation of Distress in Laboratory Animals. Recognition and Alleviation of Distress in Laboratory Animals. Washington (DC): National Academies Press (US); 2008. 3, Recognition and Assessment of Stress and Distress.

7. Andersen SL. Exposure to early adversity: Points of cross-species translation that can lead to improved understanding of depression. Development and Psychopathology 2015; 27(02): 477-91.

8. Borniger JC, Mchenry ZD, Salloum BAA, Nelson RJ. Exposure to dim light at night during early development increases adult anxiety-like responses. Physiology \& Behavior 2014; 133: 99-106.

9. Fonken LK, Finy MS, Walton JC, Weil ZM, Workman $\mathrm{JL}$, Ross J, et al. Influence of light at night on murine anxiety- and depressive-like responses. Behavioural Brain Research 2009; 205(2): 349-54.

10. Fonken LK, Nelson RJ. Dim light at night increases depressive-like responses in male $\mathrm{C} 3 \mathrm{H} / \mathrm{HeNHsd}$ mice. Behavioural Brain Research 2013; 243: 74-8.

11. Stephens MC, Wand G.Stress and the HPA Axis: Role of Glucocorticoids in Alcohol Dependence. Alcohol Res 2012; 34(4): 468-483.

12. Heim C, Newport DJ, Bonsall R, Miller AH, Nemeroff CB. Altered Pituitary-Adrenal Axis Responses to Provocative Challenge Tests in Adult Survivors of Childhood Abuse. The American Journal of Psychiatry 2001; 158(4) :575-81.

13. Daskalakis NP, Bagot RC, Parker KJ, Vinkers CH, Kloet ED. The three-hit concept of vulnerability and resilience: Toward understanding adaptation to early-life adversity outcome. Psychoneuroendocrinology 2013; 38(9): 185873.

14. Nederhof E, Schmidt MV. Mismatch or cumulative stress: Toward an integrated hypothesis of progra-mming effects. Physiology \& Behavior 2012; 106(5): 691-700.

15. Daskalakis NP, Bagot RC, Parker KJ Vinkers CH, Kloet ER. The three-hit concept of vulnerability and resilience: towards understanding adaptation to early-life adversity outcome. Psychoneuroendocrinology 2013; 38(9): 18581873.

16. Retana-Márquez S, Vigueras-Villaseñor R, Juárez-Rojas L, Aragón-Martínez A, Torres GR. Sexual behavior attenuates the effects of chronic stress in body weight, testes, sexual accessory glands, and plasma testosterone in male rats. Hormones and Behavior 2014; 66(5) :766-78.
17. Souza DD, Ribeiro C, Costa W, Sampaio FB, PereiraSampaio M. Immediate and late effects of chronic stress in the testes of prepubertal and adult rats. Asian Journal of Andrology 2018; 20(4): 385-90.

18. Iñiguez SD, Riggs LM, Nieto SJ, Dayrit G, Zamora NN, Shawhan KL, et al. Social defeat stress induces a depression-like phenotype in adolescent male c57BL/6 mice. Stress 2014; 17(3): 247-55.

19. Kalueff AV, Stewart AM, Song C, Berrigde KC, Graybiel AM, Fentress. Neurobiology of rodent self-grooming and its value for translational neuroscience. Nat Rev Neurosci 2016; 17(1): 45-59.

20. Rodriguez, A., Zhang, H., Klaminder, J., Brodin, T., Andersson, P. L. and Andersson, M. ToxTrac: a fast and robust software for tracking organisms. Methods Ecol Evol 2018; 9(3): 460-464.

21. Stefanović M, Lalošević D. Use of eriochrome cyanine R in routine histology and histopathology: is it time to say goodbye to hematoxylin? Biotech Histochem 2015; 90: 461-9.

22. Branchi I, Santarelli S, Dandrea I, Alleva E. Not all stressors are equal: Early social enrichment favors resilience to social but not physical stress in male mice. Hormones and Behavior 2013; 63(3): 503-9.

23. Canavello PR., Cachat JM., Hart PC, Murphy DL, Kaluef AV. (2013). Behavioral phenotyping of mouse grooming and barbering. UK: Cambrige, 195-204.

24. Kalueff A, Minasyan A, Keisala T, Shah Z, Tuohimaa P. Hair barbering in mice: Implications for neurobehavioural research. Behavioural Processes 2006; 71(1): 8-15.

25. Dewan A, Pacifico R, Zhan R, Rinberg D, Bozza T. Nonredundant coding of aversive odours in the main olfactory pathway. Nature 2013; 1:3: 1-4.

26. Gould T.D., Dao D.T., Kovacsics C.E. (2009). The Open Field Test. Mood and Anxiety Related Phenotypes in Mice. Neuromethods, vol 42. Totowa, NJ: Humana Press, p. 1-21.

27. Walsh RN, Cummins RA. The Open-Field Test: a critical review. Psychol Bull. 1976; 83(3): 482-504.

28. Kawashima A, Sandler CM, Ernst RD, Takahashi N, Roubidoux MA, SM, Fishman EK, N. Dunnick NR. Imaging of Nontraumatic Hemorrhage of the Adrenal Gland. Radiographic 1999; 4:2: 25-28.

29. Di Stefano M, Severino R, Coppola V, Gioiso M, Rocca R, Lisanti F, Scarano E. Nontraumatic adrenal hemorrhage: the adrenal stress. Radiology Case Reports 2017; 12:483-487.

30. Fedotova J, Akulova V, Pivina S, Dragasek J. Modifications of anxiety-like behavior in prenatally stressed male offspring with imbalance of androgens. Am J Transl Res 2017; 9(3): 1448-1459. 